\title{
Reading Ecosystem Services at the Local Scale through a Territorial Approach: the Case of Peri-Urban Agriculture in the Thau Lagoon, Southern France
}

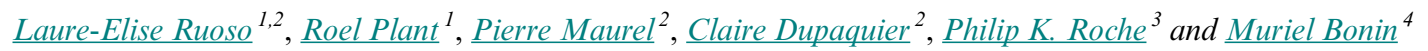

ABSTRACT. In recent years, the ecosystem services (ES) concept has become a major paradigm for natural resource management. While policy-makers demand "hard" monetary evidence that nature conservation would be worth investing in, ongoing attempts are being made to formalize the concept as a scientifically robust "one size fits all" analytical framework. These attempts have highlighted several major limitations of the ES concept. First, to date, the concept has paid little attention to the role of humans in the production of ES. Second, the ongoing formalization of the ES concept is turning it into a "technology of globalization," thereby increasingly ignoring the socio-cultural context and history within which ecosystems emerge. Third, economic valuation has been shown to limit local stakeholders in expressing their daily and immediate ways of interacting with their environment over and beyond extrinsic motivation provided by financial gains. We address these three limitations by analyzing a social evaluation of the roles of peri-urban farmland from a territorial perspective. Our case study is the Thau lagoon in southern France. We conducted in-depth interviews with a broad range of stakeholders and ran two participatory workshops. Using a territorial meta-model that distinguishes three levelsphysical, logical, and existential — stakeholder data were analyzed to unravel the interplay of territorial elements at these three levels that gives rise to ES in two broad categories: food production and aesthetic landscape. The coupling of ES and territory concepts opens up several novel analytical perspectives. It allows partitioning of ES in a manner that "re-contextualizes" them and gives insight about both their physical constituents and their meaning at the territorial level. Additional research should incorporate the dynamics of service demand and supply, and further investigate options for implementation.

Key Words: ecosystem services; local land use planning; participatory methods; stakeholder perception; territorial approach; Thau lagoon

\section{INTRODUCTION}

The ecosystem services (ES) concept (Costanza et al. 1997, Daily 1997), building on a long tradition of earlier work on humanenvironment interactions (Westman 1977, Ehrlich and Mooney 1983, De Groot 1992), was first established as an "eye opening metaphor" (Norgaard 2010:1219), which illustrated the dependence of human societies on the natural environment. Progressively, this metaphor has been subjected to growing formalization through well-established economic valuation and assessment methodologies (De Groot et al. 2002). Many "ecosystem services frameworks" have been proposed to describe and classify ES, both conceptually and in practice (Nahlik et al. 2012). The ES concept is now widely promoted as a way to identify and localize, through mapping, the values stakeholders attribute to natural ecosystems (Fagerholm and Käyhkö 2009, Raymond et al. 2009, Bryan et al. 2010, Casado-Arzuaga et al. 2013).

However, the literature points to several limitations of mainstream interpretations of ES theory and practice (Kumar and Kumar 2008, Schaich et al. 2010, Chan et al. 2012, Tengberg et al. 2012, Ernstson and Sörlin 2013, Huntsinger and Oviedo 2014, Vallés-Planells et al. 2014). We briefly introduce these challenges here to set the scene for our contribution. The arguments are elaborated in the Literature Review. First, ES are often framed without paying proper attention to the role of humans in their production: ES are merely seen as benefits that humans get from the natural environment (Challenge 1). Second, through growing formalization, ES approaches have progressively become context-free tools that neglect the historical, ecological, and social context of the place an ES approach is applied to (Challenge 2). This has led to the predominance of metrics-based valuation as the main means of apprehending ES. For example, economic valuation of ES based on standard rational choice theory overlooks the question of the immediate relationship between people and their environment: the diverse ways stakeholders make sense of, and give meaning to, their direct environments are reduced to a mere single currency (Challenge 3).

We aim to contribute to addressing these challenges by using findings from an exploratory empirical inquiry into local stakeholders' understandings and perceptions regarding their interactions with, and dependencies on, peri-urban agricultural environments. Our case study focuses on food production and aesthetic landscape services in the Thau lagoon, southern France.

We employ what we term a "territorial lens" to take into account understandings, perceptions, and uses of the territory by stakeholders, and "localize" and "contextualize" the generic concept of ES. Our premise is that a territorial perspective can mitigate both the problem of "de-contextualization" of ES production and consumption and account for the role of humans in the creation of ES (Challenges 1 and 2) (Ernstson and Sörlin 2013:281). The territorial perspective does so by explicitly taking into account stakeholders' representations, perceptions, and uses of their environment (Challenges 3).

We emphasize that we do not intend to develop yet another ES framework. Many examples exist (Costanza 2008, CREDOC 2009, Haygarth and Ritz 2009, Kienast et al. 2009, Raymond et

${ }^{1}$ Institute for Sustainable Futures, University of Technology, Sydney, Australia, ${ }^{2}$ UMR TETIS, AgroParisTech, CIRAD, IRSTEA, Montpellier, France, ${ }^{3}$ UR EMAX, TR SEDYVIN, IRSTEA Aix en Provence, France, ${ }^{4}$ UMR TETIS, CIRAD Montpellier, France 
al. 2009, Dominati et al. 2010, Maynard et al. 2010, Chan et al. 2011, Potschin and Haines-Young 2011, Sherrouse et al. 2011); however, a definitive generic framework seems to remain elusive (Nahlik et al. 2012). Rather, we aim to trial an analytic devicethe territorial lens - that can assist researchers in localizing and contextualizing the ES concept, conceived as a natural and human co-construction. By localizing and contextualizing, we mean eliciting the underlying reasoning behind stakeholders' ES evaluations and linking them to the particular physical localization and the logical and symbolic context. That is to say, we aim to better understand why and how stakeholders value particular services (symbolic context), what role our stakeholders play in the creation or maintenance of those services (logical context), and where those services emerge (physical localization).

Our territorial lens consists of three complementary analytical dimensions of a conceptual model that was first proposed by Schwarz (1992:37) to describe the "complexification and autonomization of natural systems" and was subsequently adapted to the notion of territory by Maurel (2012). First, the physical dimension encompasses the material aspect of the territory, and addresses the "where" of ES. The second dimension is the logical dimension, which addresses the question of how ES arise. The logical dimension helps describe "how" stakeholders reason about ES and their actions to enhance the presence of ES and/or reap ES benefits. Third, the existential dimension focuses on the question of "why" ES emerge, and represents their symbolic existence.

As an analytical device, the territorial lens exhibits parallels with the existing landscape studies literature's offering to complement ES studies with a "cultural landscape approach" (Schaich et al. 2010, Tengberg et al. 2012, Vallés-Planells et al. 2014). These parallels manifest most clearly in the territorial model's holistic nature, its inclusion of human actions in the valuation of ES, and its consideration of both material and immaterial aspects of the landscape. Therefore, our territorial lens can be considered as taking into account several aspects of cultural landscapes.

To address Challenge 3, we adopt a "social ES valuation" focused on the more intuitive ways stakeholders relate to their environment. Several authors have emphasized the importance of socio-cultural preference for ES besides purely economic interests (De Groot 2002, Cowling et al. 2008, Kumar and Kumar 2008, Chan et al. 2012, Martín-López et al. 2012). Studying sociocultural preferences for ES using noneconomic valuation methods allows the (shared) social values and perceptions of stakeholders, nonmonetary services, and benefits to be taken into account. This approach also develops insights into cultural services, which are otherwise often neglected (Daniel et al. 2012). Moreover, socioeconomic evaluation methods (Lynam et al. 2007) - for example, individual interviews, focus groups, or participatory mapping - offer a way to move away from ES as a rationalized normative concept and link ES to the common sense with which people relate to their environment (Kumar and Kumar 2008). Consequently, social valuation of ES allows for a better understanding of local issues and their potential inclusion in decision-making processes (Martín-López et al. 2012). A territorial lens that reveals a "rich picture" of the study area calls naturally for a social valuation of ES. The lens can be considered as a specific analytical tool to interpret qualitative data gathered through a social valuation of ES. Indeed, the three dimensions of the model explicitly refer to stakeholders' uses of a territory, and their logical and symbolic understanding of it.

\section{LITERATURE REVIEW}

The challenges evoked in the Introduction have been commented on extensively in the literature. Our brief literature review does not aim to give a comprehensive account of the state of play; rather, we highlight current debates to contextualize the three main goals of our project: (1) taking into account the human dimension of ES, (2) taking into account the context in which those ES emerge, and (3) using methods that allow stakeholders to elicit, in their own terms, the perception, representation, and uses they have of their environment.

(1) The ES concept was initially conceived as an approach to evaluate the benefits humans receive from "natural" ecosystems but neglected the role of humans in the creation of ES (Bonin and Antona 2012, Vallés-Planells et al. 2014). Progressively, the ES concept was also applied to agricultural systems, which were characterized by a much stronger role of humans in the production of services. From mere consumers of ES, people also became coproducers of ES. This change in the perception of humans' role in the production of ES requires that inputs such as capital and labor are also factored into valuations of ES. New approaches have been proposed. Huntsinger and Oviedo (2014), for example, taking a resilience perspective, have stressed the need to consider ES as social-ecological services, integrating human influences into the structure and function of ES. Taking a broader approach, several authors (Schaich et al. 2010, Tengberg et al. 2012, Vallés-Planells et al. 2014) argue for integrating a landscape perspective into ES valuation, and therefore the human dimension of ES. This approach is broader because it holistically takes into account the influence of human societies on the structure and functions of ES, as well as the representations and perceptions stakeholders attribute to ecosystems. In other words, the landscape approach to ES assessment takes into account both the material and the immaterial dimensions of ES production and consumption. As a result, humans are not only consumers but also coproducers of ES.

(2) Ernstson and Sörlin (2013:281) have argued that the ongoing formalization of the ES concept is turning it into a "technology of globalization" with four limiting dimensions: (1) "dehistoricization"- oversight of the influence of "actors, events, and processes" on ES; (2) "de-contextualization" - neglect of the "actual" use of ES in a defined area, and the eventual conflicts around them; (3) "de-ecologization"-neglect of the "holistic" dimensions of ecology; and (4) "silencing"-_giving preference to expert-driven analysis at the cost of local knowledge.

(3) Methodologically, a predominant positivistic interest in quantification, measurement, and economic valuation has been shown to limit local stakeholders in expressing their daily and immediate ways of interacting with their environment (Kumar and Kumar 2008). Standard monetary valuation of ES is essentially a normative process embedded in a particular model and assumptions of human behavior (Vatn 2005, Spash 2008). As such, it does little to elucidate interdependencies between societies and their environments. Rather, it separates (alienates) people from their environments. Recent ES research has started to tackle these limitations (Asah et al. 2014, Kenter et al. 2015). For 
example, Asah et al. (2014) studied the behavioral dimensions of ES, asking "how human motivations to acquire and use ES may mediate people's responses to ecosystem management and policy" (Asah et al. 2014:1). These motivations were studied through open-ended interviews, which allowed stakeholders the freedom to express themselves using their own framings.

\section{METHODS}

For this study, we focused on identifying ES attributed to the agricultural lands of three municipalities in the Thau lagoon in southern France. The Thau lagoon is a peri-urban area southwest of the city of Montpellier. The area is facing the challenge of urban sprawl at the potential cost of agricultural lands. As a consequence, the extent of fallow land has increased in recent years. In this context, a study of ES associated with agricultural lands enhances and articulates the roles local stakeholders attribute to these spaces. We worked in close partnership with the Syndicat Mixte du Bassin de Thau (SMBT), a public engineering agency responsible for managing natural resources and urban development in the Thau lagoon. We conducted individual interviews and collective participatory workshops. Data were analyzed using the territorial meta-model described in the Introduction.

\section{Case study description: Thau geography}

The Thau lagoon is situated in Languedoc-Roussillon region, southern France (Fig. 1). It comprises a 44,000-ha catchment situated around a 7500-ha lagoon, called the Thau lagoon. This territory is characterized by diverse landscapes (agricultural plains, "garrigues" [the local name of low-to-medium height Mediterranean evergreen shrub vegetation], woods, wetlands, and lagoons) and activities. Economic activities are strongly influenced by the presence of the lagoon, and include shellfish farming and fishing activities. Agricultural lands and activities still play an important role, despite urban sprawling (agricultural lands represent $47 \%$ of the territory). The main agricultural activity in the catchment is wine-growing $(33.5 \%$ of the Thau lagoon's agricultural lands (Blezat Consulting 2011). Other agricultural activities include cereal farming, market gardening, fruit growing, and dairy farming.

The Thau territory has two intermunicipalities. The SMBT implemented a Schéma de Coherence Territoriale (SCoT), a spatial planning document that integrates sectorial policies, for these intermunicipalities. The SCoT encourages the intensification of urban development in the triangle of the villages of Sète, Frontignan, and Balaruc-les-Bains (Fig. 1), and the conservation of farmlands in the northern part of the lagoon (mainly around Villeveyrac, Loupian, and Montbazin) (SMBT 2013).

Our case study area is located in the northern part of the territory (Fig. 1), where farmlands still have the potential to be preserved. The area encompasses three municipalities with different characteristics on a geographical gradient that goes from the lagoon to the inland region.

\section{Case study region - institutional arrangements}

The study area was identified in consultation with the SMBT, whose staff has intimate knowledge of local stakeholders' interests and debates. Their activities in urban development, water quality management, natural area protection, and the agricultural sectors typically involve local stakeholders, using various types of consultation processes.
Fig. 1. Case study area.

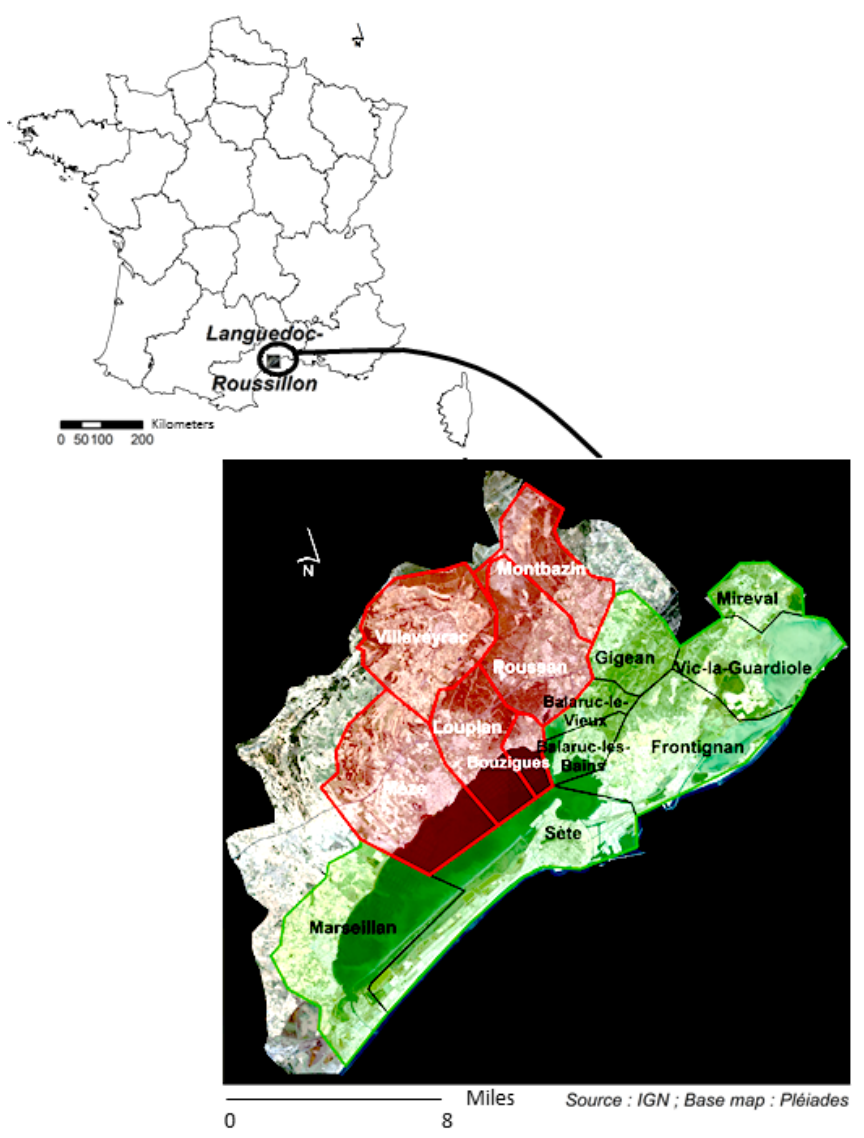

Legend

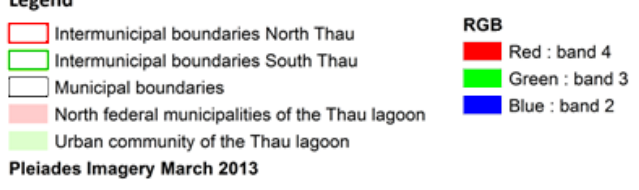

Agricultural character of the villages of Villeveyrac, Loupian, and Mèze

The village of Villeveyrac has a strong agricultural identity, which is stimulated by agricultural diversification, a relatively large farmer population, a local irrigation network, and processes like land reparceling. The political vision for this municipality favors agricultural development through advocacy for agricultural land conservation and promotion of local agricultural production.

Loupian, on the other hand, has undergone a strong abandonment of farmlands due to a combination of factors. The political vision for the municipality favors natural landscapes over agricultural lands. Moreover, Loupian has poorer soils than those found around Villeveyrac, and is closer to a highway and a main road. These combined factors make the village less attractive to farmers. Loupian's wine-growing cooperative merged with a larger one in another village, which has played against the agricultural vitality of Loupian. The process of abandonment of farmlands has resulted in an increasing area of fallow lands and a declining farmer population. 
The village of Mèze is the southernmost settlement in our case study area. It has a strong maritime identity due to activities related to the lagoon (shellfish farming, fishing, boating). However, agricultural activities, which benefit from an irrigation network and good soil quality, are also important. In this area, vineyards have increasingly been subsumed by production of melons and durum wheat.

\section{Data acquisition: individual interviews, and collective workshops}

\section{Stakeholder recruitment}

We used two social research methods in conjunction: individual interviews and collective workshops. To identify suitable stakeholders, we first engaged with the SMBT to establish a list of people with both an agriculture-related stake in the Thau territory and a potential interest in participating in research (the Thau region has a long history of participating in research). We distinguished between (1) people who work directly or indirectly with agricultural lands, such as farmers or land managers, (2) people who use agricultural lands primarily for recreational activities, and (3) people who are professionally impacted by agricultural lands or agricultural activities, such as fishers and real estate agents. We conducted individual interviews with 21 stakeholders and designed two participatory workshops. At the end of each interview, we asked the interviewee to nominate others who might be interested in participating in our project (i.e., a snowballing process). Eight stakeholders were present during the first workshop; 16 were present during the second.

In terms of representativeness of our stakeholder selection, the snowballing process kept our selection of participants largely within the core network of the SMBT staff and their stakeholders. Consequently, we had access mainly to people who were strongly involved in the territorial management of the area. As such, the results of our study, which was focused on methodological development and testing, may not reflect a fully balanced stakeholder view of the role of farmlands in the area.

\section{Individual interviews}

Individual interviews lasted between 30 and 90 minutes. During these interviews, we did not explicitly introduce the concept of ES but rather used questions about stakeholders' uses, perceptions, and representations of the territory and agricultural areas (Appendix I). All interviews were recorded and transcribed. The content of these interviews was coded using basic ES categories (explained further in Data analysis).

\section{Participatory workshops}

We conducted two collective workshops, each with a different objective. The first workshop focused on selecting and grouping ES from a generic list of 31 services derived from the ES literature (Appendix 2 and 3). We avoided the explicit use of the words "ecosystem services," which we considered as too academic for our context. Participants were asked to select the labels or phrases that best captured the current roles of farmlands for them. The second participatory stakeholder workshop, lasting four hours, was designed to allow participants to position their previously chosen ES geographically on a high-resolution multispectral satellite image. The map, intended as a supporting device (Star and Griesemer 1989), was color printed in A0 size, and the legend comprised the municipalities' boundaries, the hydrographic network, the names of the three municipalities, and selected key spots in the territory (e.g., the Valmagne Abbey and the location where the workshop was held). During this workshop, 16 stakeholders were present. They were placed into four subgroups of four. Each subgroup first specified and positioned selected services on the color map. For example, for the "wild fruits and vegetables picking" service that the territory provides, several types of picking exist: e.g., berries, asparagus. During the second part of the workshop, the subgroups employed a two-dimensional matrix as a supporting device. The columns of this matrix represented the service categories discussed by the participants while they placed them on the map. The rows represented the physical factors that determine the presence of a service in the territory, such as land cover, landscape features, farm structure, and other biophysical parameters, such as relief, topography, and seasonal phenology. These physical elements had been previously identified by stakeholders during individual interviews and the first workshop. Each group was asked to associate each category of services identified with the physical factors that favored its presence in the territory. The use of the matrix was intended to capture the key physical features that stakeholders deemed relevant for ES production and consumption.

\section{Data analysis: content analysis using a conceptual territorial meta-model}

First level of analysis

To analyze the qualitative data obtained from the individual interviews, we identified keywords that could be linked to services on the initial list of 31 services, as well as new elements. We drew up a list of every service mentioned, and quoted, for each interviewee, the sentences that best illustrated the service. We also noted if this service was considered by the interviewee as present, not much present, or in danger, and if in danger, for what reason. We also identified modifications of practices, or the implementation of infrastructures considered by actors, as elements that could favor the presence of a service in the territory. Finally, actors also mentioned some negative impacts caused by agricultural practices; for example, downstream impacts of polluted runoff from farmland upstream. For each service, modification of practice, implementation of infrastructure, or negative impacts (Zhang et al. 2007), we identified the type of land cover and the municipality with which it was associated, when stakeholders made it explicit. The small number of stakeholders interviewed, the open-ended form of the interviews, and the broad range of ES brought up during the interviews necessarily imply that some aspects of services considered in the study were evoked by only a few stakeholders, and may therefore be subject to controversy. Hence, our results should not be read as a comprehensive and representative account of stakeholders' perceptions of ES provided by farmlands in the Thau lagoon. Rather, we focus on a methodological advancement - the use of a territorial lens for understanding the "story behind" ES from peri-urban farmlands at the local scale.

The data obtained during the workshops complemented those obtained during the individual interviews. After systematic treatment of the individual interview data, selected aspects were analyzed further using a territorial lens, or meta-model.

\section{Systematic analysis using a territorial meta-model}

Our territorial lens is a simplified version of the territorial metamodel developed by Schwarz (1992) and adapted by Maurel 
(2012). The model has its origins in cybernetics and describes the evolution of systems toward complexity and autonomy. Our metaphor of a lens refers to the territorial meta-model as an analytical device to contextualize and localize ES that emerge from a territory. The lens is comprised of three intertwined levels (Fig. 2). The physical level is the level of matter and energy. It encompasses all objects of the physical world as well as (noninterpreted) anthropogenic phenomena like stakeholders' practices or socioeconomic activities. The logical level reflects the interpretation of this physical reality by stakeholders. It is the dimension of the conceptualization, or processing, by territorial actors of the physical elements. Here, the mental frameworks through which stakeholders understand their territory are built up. The logical dimension also encompasses all the actions in which stakeholders are involved in the territory. Thus, the logical dimension simultaneously takes into account cognitive elements, making up the understanding of their territory by stakeholders, and organizational elements; i.e., the actions implemented by stakeholders on the territory. Third, the existential level is the level of the territorial identity. It encompasses the symbols stakeholders refer to in order to define their territory, distinguish it from other territories, and show their feelings of belonging to this specific territory. The existential dimension is the dimension where meaning arises.

Fig. 2. Territorial meta-model. Simplified version of the territorial meta-model developed by Schwarz (1992) and adapted by Maurel (2012). The model has its origins in cybernetics and describes the evolution of systems toward complexity and autonomy.

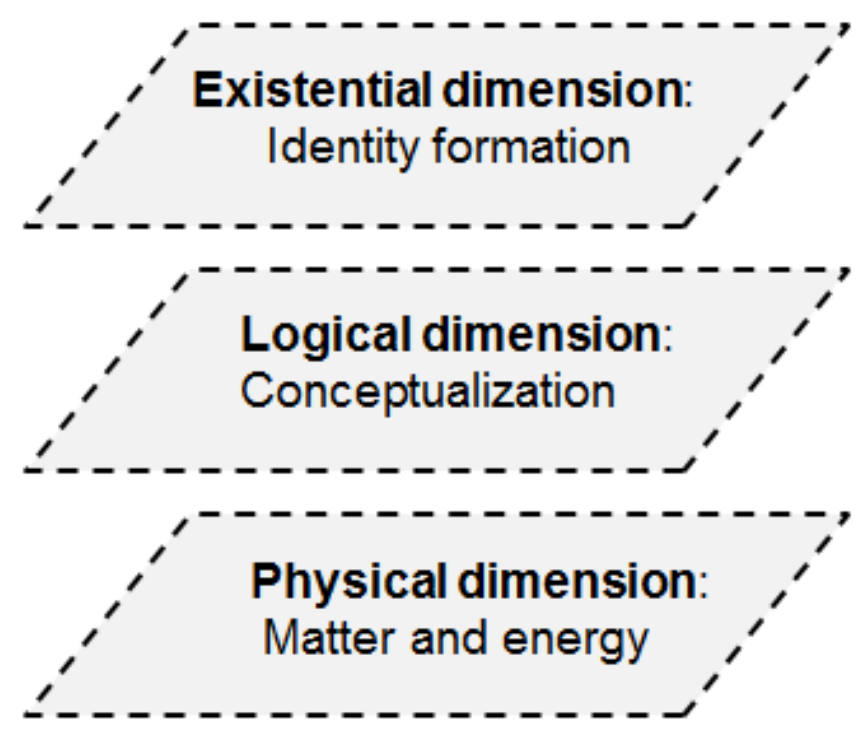

The territorial meta-model also captures the evolution of the territory through time, addressing its capacity to adapt to internal and external shocks and remain resilient. We focus on the three intertwined levels (vertical dimension) only because our shortterm study did not capture the dynamic (horizontal) dimension.

The vertical dimension of the territorial model offers several advantages as an analytic device. First, it allows identification of the physical elements participating in the presence of a service at multiple scales. Second, it considers the anthropogenic dimension of ES production in various ways: through direct human actions in the territory (agricultural activities, agricultural products, ways of commercialization), through the way humans conceptualize and promote some activities, and through the symbolic significance they attribute to objects in the territory.

\section{RESULTS}

Our aim is to better understand why and how stakeholders value particular ES (contextualization) and where (localization) these services emerge. In this section we illustrate how an analysis of ES through a territorial lens can help characterize the "story" behind a service. The first step is localizing it through the identification, at the local scale, of the physical elements attached to it (physical dimension). Second, the service is contextualized by identifying how it is promoted through cognitive and organizational processes (logical dimension) and what significance stakeholders give to the service (existential dimension). We use two broad service categories-food production and aesthetic landscape - as perceived by stakeholders in the Thau lagoon, as examples.

\section{Food production}

Food production was, unsurprisingly, one of the most important services provided by farmlands. However, stakeholders insisted on the importance of the locality of food production and consumption and the perceived appropriateness of crops in the local environment. Several stakeholders shared the viewpoint that the agricultural produce of the territory should feed the local people and fit the local landscape and conditions. However, some stakeholders challenged the local food provisioning role and the legitimacy of some crops. The presence of certain crops at the physical level was both challenged and endorsed at the logical level, depending on the particular reading frame of stakeholders (e.g., the perceived role of crops as local food, and its perceived appropriateness in the environment).

The south of our case study area is characterized by the presence of melons and large-scale arable crops (wheat and corn). For several reasons, those cultures were perceived as "out of place" by some stakeholders.

First, some products in this area, like melons, are grown primarily for exportation and therefore do not play a role in local food provisioning. One stakeholder offered that:

"We are surrounded by lands that don't really feed us. We will never touch those melons because they pick them up when they are still green and send them to Holland."

Second, intensive agriculture was sometimes considered as "out of place" in a fragile ecosystem like the Thau lagoon. The reasoning of some stakeholders pertained to the need for irrigation in a dry area and the polluting impacts from those crops: "Corn fits nowhere in the Mediterranean because it needs to be irrigated" or "[...] melons are more problematic than vineyards because a lot of fertilizers [...] are [being] used."

Furthermore, the presence of such crops results in landscapes that some stakeholders did not see as part of the local landscape. Whereas some consider the northern part of the territory as a living reminder of the influence of the Romans on the landscape 
(alternation of vineyards, wheat, and olive groves), one stakeholder described the southern part as "less enjoyable" because of the intensity of agriculture and the size of the fields.

Another major agricultural product, wine, produced on a major proportion of agricultural lands in the Thau territory $(33.5 \%)$, has an ambiguous status for stakeholders (Blezat Consulting 2011). Its quality as "food" is challenged:

"When we talk about wine, can we consider it as food?"

When a crop's quality as food is not challenged, its necessity in daily life is challenged. Several stakeholders argued that "wine is not a necessity," and even if vineyards are often considered as less "polluting" than melons or corn crops, they are still a matter of concern on the lagoon. However, wine represents an important production system and an important crop in the Thau territory if we consider the historical and aesthetic aspect in the territory. Moreover, a few wine growers are selling wine locally, giving it the status of local produce.

Other foods are considered as having a clear nutritional role at the local scale; for example, the fruits and vegetables produced by market gardeners, or the goat cheese produced by one business in Villeveyrac. The presence of this type of agricultural produce was not challenged during the interviews, even if problems of pollution were sometimes evoked in relation to market gardening activities.

In summary, food production is not merely a matter of the type and quantity of crops that are being cultivated. For our stakeholders, the notion of food production also pertains to the food provisioning role of crops at the local scale, and the perceived appropriateness of crops in the context of their local environment.

However, food production was also characterized by stakeholders in terms of the mechanisms of commercialization of agricultural produce at the local scale and the discourses (at the logical level) and symbolisms (at the existential level) that sustained those mechanisms.

The products that are considered as totally or partially provisioning food at the local scale and are therefore considered as playing an important food production role in the territory acquired this status because they are sold at the local scale, through different sales mechanisms, implemented at the physical level. These include sales by individuals, associations of producers, or municipalities. There exist both traditional and more recent sales mechanisms, the latter being supported by a discourse (at the logical level of the territorial model) about a certain vision of agricultural production and the producerconsumer relationship. The sale of local products occurs on a daily or weekly basis as well as during occasional events.

At the individual scale, current sales practices in the area include the sale at the doorstep or at the farm. These sales mechanisms have existed for a long time. A recently established sales mechanism is the Association for the Maintenance of a Traditional Agriculture (AMAP [Association pour le Maintien d'une Agriculture Paysanne]), where the consumer buys a basket of vegetables and fruits directly from the producer at a predefined, fixed price. AMAP supports farmers during the winter months, when production is low. It reflects a rethinking of the relationship between producer and consumer, at the logical level, through such concepts as a solidarity-based economy and responsible consumption.

At the collective scale, some established sales mechanisms (e.g., wine grower cooperatives) continue to exist. These are being supplemented by a producers' shop which brings together several local farmers, oyster growers, and fishers. This shop enables producers to directly sell their products to the consumers. A recent sales initiative is the "Thau basket" (panier de Thau); it brings together seafood and terrestrial produce, which are sold following a process similar to that employed by AMAP.

Other initiatives are taken at the municipal level, especially in Villeveyrac, where the promotion of local products is an important aspect of local agricultural policy. The Villeveyrac municipality organizes annual producer markets, where farmers can sell their products. The municipality also organizes an annual festival called the "fête des genêts," where both local producers (from Villeveyrac) and producers from the region can showcase and sell their products (Fig. 3).

Fig. 3. Villeveyrac's systemic vision of agriculture. This diagram illustrates how "short-circuited" agriculture in Villeveyrac impacts producers, the community, and the village as a whole.

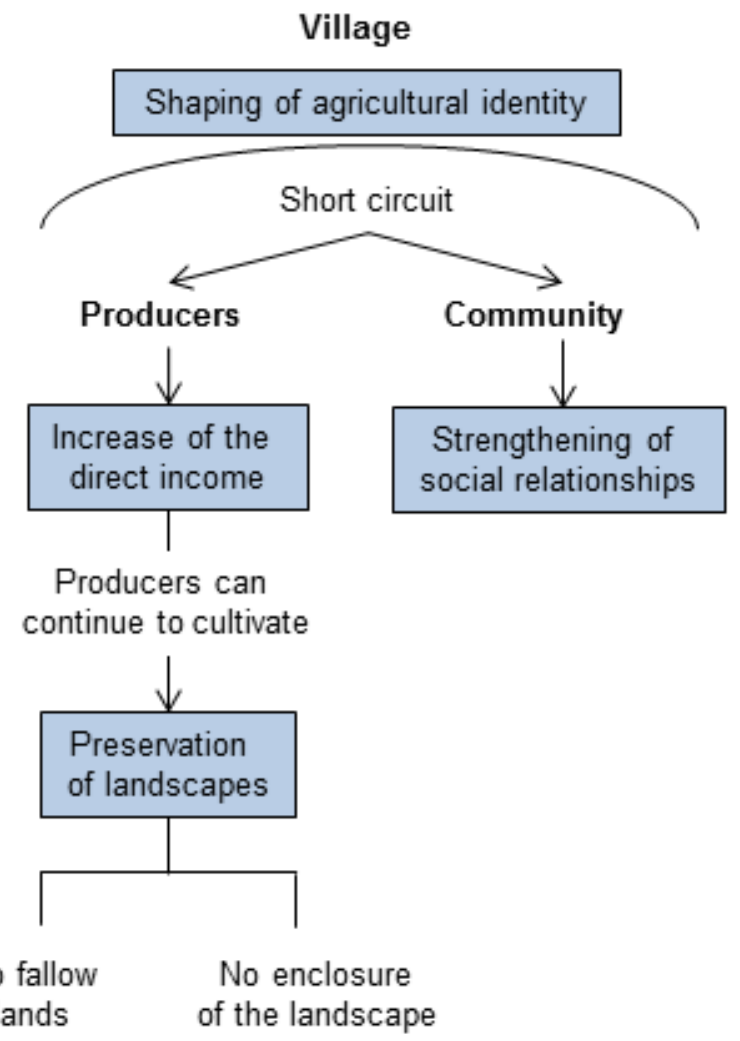

Legend:

Ecosystem services preserved

Scale 
Some of these sales initiatives are supported, at the logical level, by a discourse about local food provision, particularly in the village of Villeveyrac. In this village, situated in the north of our case study area, a systemic short-circuit vision of agricultural activities is promoted. Indeed, according to some stakeholders, short-circuit consumption triggers a positive feedback loop: first, it improves the standard of living of farmers by increasing their direct income without requiring enlarged exploitation, and thereby enables farmers to continue to cultivate their lands. As a consequence, farmers continue to maintain the landscape by preventing it from fallowing (in the case study area, fallowing is the typical consequence of terminated agricultural activity). At the community level, short-circuited agriculture also strengthens social relationships within the village through participation of producers and consumers in different regular events. These include weekly events, such as the AMAP and the Thau basket, but also yearly events like the fête des genêts and the producers' markets. This positive feedback loop, triggered by short-circuited consumption, forms the basis of Villeveyrac's claims to an identity as "rural municipality" at the existential level: agricultural activities become a core aspect of Villeveyrac's definition of itself. For the two other villages in our case study area, the situation is different: Mèze, which is located right on the lagoon, is focused primarily on maritime activities; Loupian is progressively losing its agricultural activities.

The use of the territorial lens allowed a distinction between the agricultural products of importance in the territory (physical level) and their perceived "legitimacy" (logical level) based on their role in local food production and their perceived appropriateness in the local environment (Fig. 4).

We also found that the role of certain products as local food is sustained by different sales mechanisms (physical level), ranging from the individual selling at the doorstep to communal events organized and framed by municipalities. Some of these mechanisms are endorsed by discourses (logical level) that argue for stronger links between producers and consumers. Examples include the AMAP and the systemic vision of agriculture held by the municipality of Villeveyrac.

Such discourses can shape the symbolic character of the territory at the existential level. This is the case for the municipality of Villeveyrac, which conceives of itself as a rural municipality. This demonstrates the combined influence of the three cybernetic dimensions of a territory in the construction of the food production service.

\section{Aesthetic landscape}

Stakeholders associate aesthetic qualities of landscapes at the physical level with several scales, going from the plot/field scale to the Thau lagoon as a whole, via intermediate scales (e.g., combined landscape features), but also with seasonal phenology and topography (Fig. 5).

First, at the plot scale, stakeholders consider the wine-producing areas and their changing seasonal colors as an essential element of their landscape. As one stakeholder remarked:

"All the vineyards in the fall, with their variations of colors, red, yellow, it's magnificent."
Fig. 4. The food production service in Thau lagoon. Food production relies on its provisioning role and the perceived appropriateness of crops in the local environment (AMAP: Association pour le Maintien d'une Agricultural Paysanne).

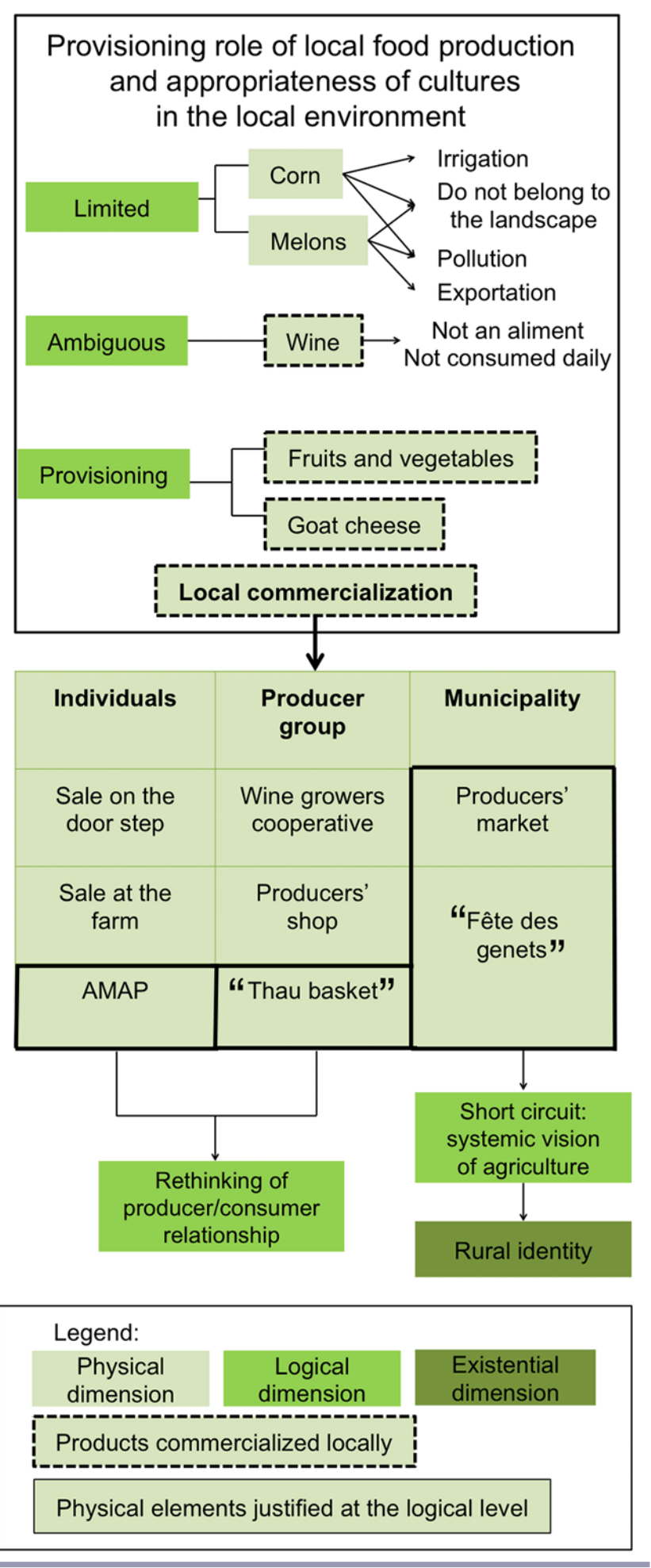


Fig. 5. The aesthetic landscape service in Thau lagoon. Different physical, logical, and existential elements interact to generate the aesthetic landscape service.
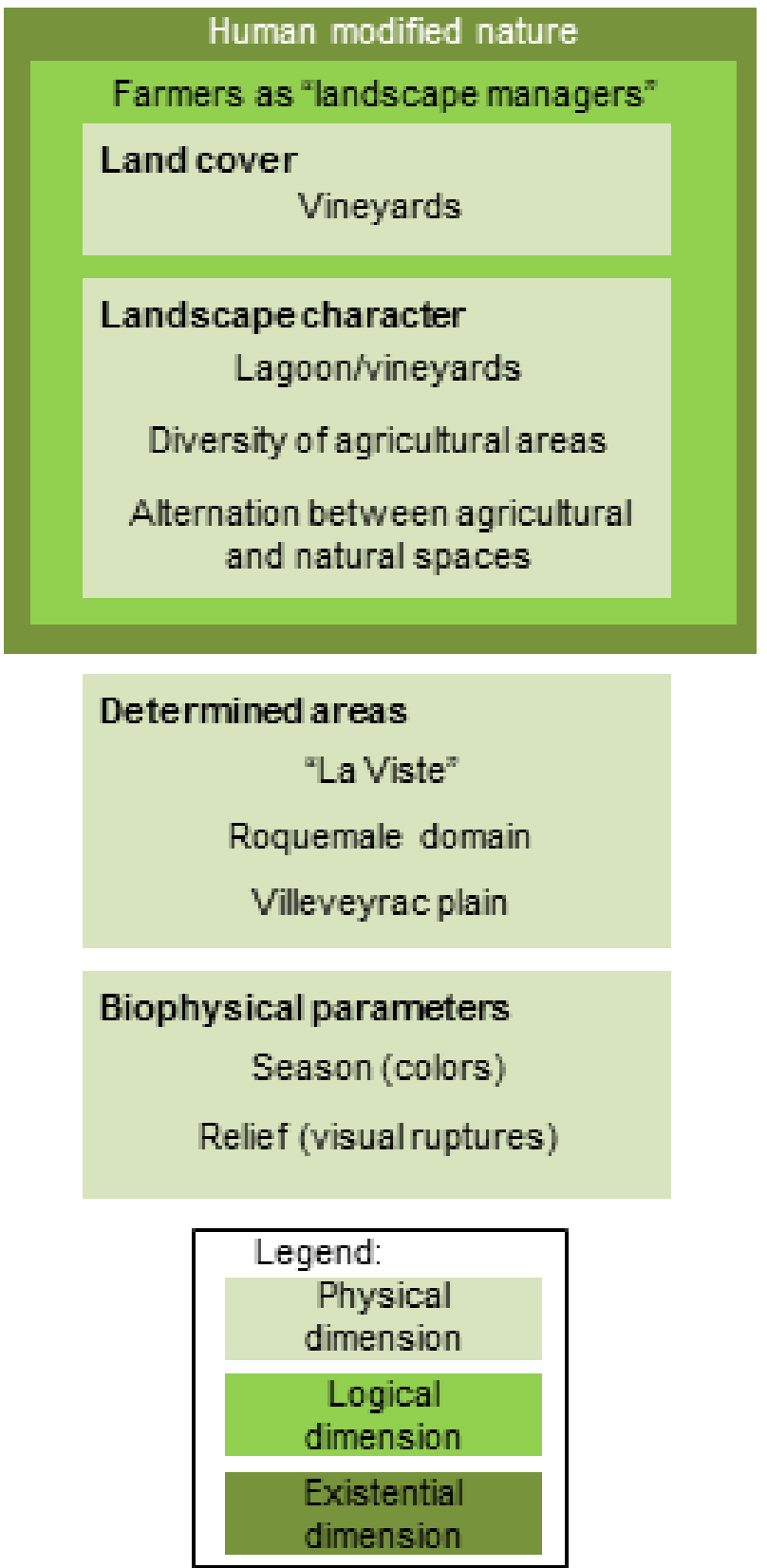

"[..] in Villeveyrac [...] we had [..] the Servant which was a table grape, which ripened later. So, when it comes to changing colors, it lost its leaves later. We had a lot of Alicante Bouschet which was red purple, the Grenaches which were a little bit yellow, the Carignan, which was green, and then dappled themselves with purple too."

Second, combined landscape/vegetation features were also considered as being an important aspect of stakeholders' aesthetic perception of the landscape. Stakeholders mentioned crop diversity (mainly the alternation of wheat fields, olive groves, and vineyards) as practiced around Villeveyrac. Crop diversity was seen as declining progressively toward Loupian, where fallow lands are abundant, and Mèze, where intensive agriculture, with much larger lots and less diversity, can be observed. One stakeholder illustrated this point as follows:

"Villeveyrac is still really beautiful, there is a landscape, when we go down from the Saint Pargoire road [...] there is at the same time a bit of wheat, a bit of vineyard, some olive groves. It looks as if we are still in Roman times. It's really magnificent."

"Near Mèze [...] we have big fields [...] melons fields, [...], in my opinion some regroupings of land have been made, there are big surfaces, we are outside the beautiful landscapes there, we are really in more intensive agricultural areas."

The second combined landscape/vegetation feature that local stakeholders valued is the mosaic of agricultural and natural spaces at different scales. First, there is the alternation between natural vegetation and farmland:

"We went to Besilles, Castelnau-de-Guers, where there are trees, high pine trees $[. .$.$] with scrappy vineyards in the middle of pines,$ etc... It's magnificent."

"I like strolling into places where agricultural areas mingle with more protected areas."

Furthermore, there are farmlands and their connecting vegetation, such as hedges, copses, or "garrigots" (subsections of garrigues) alternating with cultivated spaces:

"The garrigots [...] these are stones with trees, and it is part of the landscape, I find them really pretty."

"What bothers me a little bit about vineyards is [..] that there are no more copses left, no hedges. We really max out our [agricultural] profits..."

Third, some farmlands are also valued when they are linked with water bodies that have extreme importance in the Thau lagoon. Indeed, some vineyards are considered almost as extensions of the Thau lagoon:

"When you are in Castelnau-de-Guers you can see the sea. It is magnificent. With vineyards which extend it sometimes."

Finally, stakeholders considered relief as an essential biophysical landscape component. They mentioned "combes" (valleys) and rocky uplands as providing visual discontinuity.

The analysis suggests that farmlands, at different scales of apprehension (from the plot scale to the scale of combined landscapes features), and sometimes associated with seasonal variation, natural areas, or water areas, constitute an important element of the aesthetic perception that stakeholders have of their territory. At the logical level of our territorial model, the importance given to the presence of farmland is reflected by the fact that stakeholders perceive farmers as important actors in the modeling of the landscape. The natural resource managers that we interviewed often said that farmers' actions, especially those of wine growers, prevent such phenomena as fallowing (which in turn often leads to urbanization) and overgrowth of the landscape by garrigues. This discourse is also echoed by farmers themselves 
and other stakeholders. Farmers often speak of their activity as a way to "maintain" landscapes, and to shape it.

The idea of farmers actively contributing to the maintenance of landscapes is sustained in the existential dimension of the territorial model: local stakeholders often consider the Thau territory as an entirely anthropogenic, human-made space, regardless of the omnipresence of what we have called natural spaces. When the term "natural spaces" was used, stakeholders often questioned their existence:

"Natural spaces? What are natural spaces?" or "It is fundamental to preserve the farmlands and 'natural spaces,' even if the latter are not natural."

This view was particularly strong when the garrigue was considered, which several stakeholders considered as humaninduced vegetation. Garrigue is often classified as natural vegetation because human activity in garrigue is not as important as it was in the past. However, local stakeholders considered garrigue as totally shaped by human activities, and deemed the actual decrease of agricultural activities in those areas as a loss:

"The garrigue is a landscape that has been completely shaped [...] by pastoralism, and, by the way, it is a shame that there is nearly no pastoralism left [...] It is never totally natural, man is everywhere."

"Considering agriculture, speaking of past centuries [...] when you look at spaces considered as natural, that is to say the garrigue, actually this was a cultivated space [...] I would like to see olive groves planted again, but economically it's not viable."

Stakeholders also often saw farmers as essential to the provision of landscape services because they "maintain," or "carve" the landscape and ultimately prevent it from falling prey to urban sprawl:

"Vineyards also abate urbanization [...] because fallowed land gets more easily urbanized [..] than productive land, where there is an economy."

In conclusion, our findings indicate that the construction of the aesthetic service rests mainly on physical elements of different types, where agricultural elements play an important role. Nevertheless, the appreciation of those elements is partially determined by stakeholders' perception (at the existential level) of humans as part of nature, and consequently of farmers as managers of the environment (at the logical level). This conception of human/nature relationships at the existential level can partially explain the importance of agricultural elements in people's landscape preferences.

\section{DISCUSSION}

Strengths of reading ecosystem services through a territorial lens Our exploration of the analytical uses of a territorial lens in an exploratory case study of social ES valuation aimed to contribute to the creation of solutions to three challenges: (1) the human dimension of ES, (2) the "re-contextualization" of ES, and (3) giving a voice to stakeholders' perceptions.

Our discussion first reflects on how each level of the territorial lens contributes to fulfilling this goal. We then move to a reflection on the limitations of our approach.
The first level of the model (physical dimension) can help establish a typology of physical elements, at different scales, identified by stakeholders as prerequisites for the existence of a service in the territory. There is extensive research on stakeholders' identification of the physical elements comprising ES, particularly through participatory mapping (Raymond et al. 2009, Bryan et al. 2011). The identification of physical elements that comprise the presence of an ES is important because these elements can be linked to the logical and existential dimensions of the model, which gives insights about the role of humans in the creation or maintenance of those elements and their symbolic meaning.

Indeed, the elements pertaining to the logical level can first be used to identify how stakeholders perceive the role of human beings in the creation or maintenance of ES. For example, our stakeholders saw farmers as contributing to the maintenance of an aesthetic landscape in the Thau area because of their role as "managers of landscapes." Second, mapping physical elements can also yield insights about the mental constructs that stakeholders employ to articulate the presence of an ES in the territory, and to dismiss or legitimate it. For example, the systemic short-circuit vision of agricultural activities as promoted in Villeveyrac aims at justifying the food production service in this village. Here, the logical dimension operates as an integrator of the human dimension of ES (Challenge 1) by acknowledging the role of humans in creating or maintaining ES. It also contributes to the re-contextualization of ES by taking into account the way stakeholders are legitimating or contesting the presence of an ES in a territory, eliciting the rationale that is accompanying it in a specific context (Challenge 2).

The elements of the existential level are also important for a better contextualization of ES (Challenge 2); they highlight key aspects of the relationships between stakeholders (or local communities; e.g., Villeveyrac) and the environment. This allows the researcher to link stakeholder perceptions of physical elements that play a role in the creation of ES to their broader conception of, for example, what is "natural," or what "naturally exists." The wider conceptions stakeholders have of human relationships with nature are also an element of contextualization of ES because these conceptions can vary from one location to another. Understanding such conceptions can explain why stakeholders positively assess some physical elements while they respond negatively to others. For example, human-made agricultural elements are an important aspect of the aesthetic landscape for the stakeholders of the Thau lagoon because they do not perceive any landscape as "natural," and they consider farmers as managers of the landscape, not destroyers of nature. Their affection for agricultural elements is therefore linked to their conception of the farmer/nature relationship.

Finally, the framing of our case study as a social valuation of ES helped address the identified limitations of a perceived need for metrics and quantification, including economic valuation (Challenge 3). Our case study opened up the possibility to have access to more immediate perceptions of stakeholders. Indeed, through the interviews, the question of ES was approached indirectly (i.e., we asked about "roles" of peri-urban landscapes rather than ES from these landscapes). Stakeholders therefore had the opportunity to express their relationships with their environments in their own words. 
Our case study was exploratory, and as a first attempt, it has laid bare several limitations that need to be acknowledged. These are discussed in the next section.

\section{Limitations}

The first limitation we encountered concerns stakeholder suspicions about ES, particularly the identification of physical elements. Particularly farmers expressed such suspicions in our case study. Indeed, when working with stakeholders on locating particular ES, some were worried that mapped ES could become the basis of formal planning documents, which would add further constraints to their practices, whether professional or recreational. We suggest that the status of cartographic outputs from participatory settings - that is "by picking participants' brains" - has to be clearly agreed upon in advance by all participants. In addition to research ethics, another important consideration is the validity domain of such cartographic outputs. Maps derived from participatory sessions have limited use as de facto standards because their domains of validity are inherently constrained by the selection of local stakeholders and the framing questions these stakeholders were asked to consider.

A second limitation concerns the time scale of our case study research. Ernstson and Sörlin (2013:277) have argued that value articulation is "an empirical body of practices that is played out in e.g. science, media, policy, and through the action of identifiable social actors that make use of technologies or artifacts to establish or articulate values," and insist on the importance of the process of construction of these values, on the conflicts and contestations they generate, and on how, in this process, some stakeholders can be marginalized and therefore silenced. Our participatory design did not capture longer term processes of value construction or marginalization; hence, our results offer only a snapshot of the current situation. Moreover, to be complete, the description of the articulation of values should take into account several trends among stakeholders, and give a voice to those who have been marginalized during the longer term process of value construction. In our work, due to time constraints and stakeholders' limited willingness to be involved, we had access only to stakeholders who were already somehow involved in territorial planning and were (therefore) keen to participate. We did not interview the marginalized people that Ernstson and Sörlin (2013) evoke. Our snapshot is therefore monolithic and arguably misses the complexity of the history of social reality of our study area.

\section{CONCLUSION}

We have provided some insight into how a social valuation of ES, through a territorial lens, can mitigate some limitations associated with mainstream interpretations of the ES concept. In summary, the territorial lens, as an analytic device within a social valuation of ES, could adequately take into account the human dimension of ES (Challenge 1), re-contextualize ES (Challenge 2), and allow stakeholders to talk about their immediate link with the environment without the need for prior quantification or measurement (Challenge 3).

Due to the exploratory nature of our case study, several challenges remain. Future research could further explore social realities in order to give a more nuanced picture of a study area. Such a study could consider the dynamic dimension of the territorial model
(Maurel 2012), which we have ignored due to the short time frame of our case study. The dynamic aspects of the model could, for example, analyze the evolution of ES in the territory (e.g., change of service levels, change in structure and form of services, change in meaning of services).

Another area for future research is the degree to which partitioning ES based on a territorial reading frame is consistent with current French territorial planning and its data and information needs (Maurel 2012, Bertacchini et al. 2013). In addition to the possible uses of ES information in French territorial planning, there are questions about alignment of process and the degree to which our tested approach to social valuation should be codified and simplified in order to be found practicable. This may involve moving toward quantitative rather than qualitative data, and simplifying the mapping process. Finally, future stakeholder engagement around territorial planning projects could be enriched with maps of ES supply (Martínez-Harms and Balvanera 2012, Schulp et al. 2012) so as to confront perceptions of and demand for ES, with the physical reality of their presence and production possibilities. Indeed, an analysis of socio-preferences of ES would merit substantially from being coupled with biophysical analysis of the landscape in order to further explore the complex links between biophysical elements, ecological processes, and perceived ES (Crossman et al. 2013). Spatial modeling based on satellite imagery or existing spatial databases could be employed subsequently to map ES at different scales.

Responses to this article can be read online at: http://www.ecologyandsociety.org/issues/responses. $\mathrm{php} / 7694$

\section{Acknowledgments:}

We thank SMBT staff for their support of, and participation in, this research project. We are grateful to our workshop participants for their time and effort. Funding for this research was provided by the French National Research Institute of Science and Technology for Environment and Agriculture (Irstea). Additional funding for writing this article was provided through its Irstea's AOIPREMEX funding scheme.

\section{LITERATURE CITED}

Asah, S. T., A. D. Guerry, D. J. Blahna, and J. J. Lawler. 2014. Perception, acquisition and use of ecosystem services: human behavior, and ecosystem management and policy implications. Ecosystem Services 10:180-186. http://dx.doi.org/10.1016/j. ecoser.2014.08.003

Bertacchini, Y., P. Maurel, P. Déprez, and R. Plant. 2013. Spatial information \& communication arrangements: a contribution to territorial intelligence. Journal of Emerging Trends in Computing and Information Sciences 4:19-28.

Blezat Consulting. 2011. Etude action sur le développement de la filière agricole sur le territoire de Thau Agglomération. 
Bonin, M., and M. Antona. 2012. Généalogie scientifique et mise en politique des services écosystémiques et services environnementaux. VertigO 12:2-10. http://dx.doi.org/10.4000/ vertigo. 13147

Bryan, B. A., C. M. Raymond, N. D. Crossman, and D. King. 2011. Comparing spatially explicit ecological and social values for natural areas to identify effective conservation strategies. Conservation Biology 25:172-181. http://dx.doi.org/10.1111/ j.1523-1739.2010.01560.x

Bryan, B. A., C. M. Raymond, N. D. Crossman, and D. H. Macdonald. 2010. Targeting the management of ecosystem services based on social values: where, what, and how? Landscape and Urban Planning 97:111-122. http://dx.doi.org/10.1016/j. landurbplan.2010.05.002

Casado-Arzuaga, I., I. Madariaga, and M. Onaindia. 2013. Perception, demand and user contribution to ecosystem services in the Bilbao Metropolitan Greenbelt. Journal of Environmental Management 129:33-43. http://dx.doi.org/10.1016/j.jenvman.2013.05.059

Chan, K. M. A., J. Goldstein, T. Satterfield, N. Hannahs, K. Kikiloi, R. Naidoo, N. Vadeboncoeur, and U. Woodside. 2011. Cultural services and non-use values. Page 365 in P. Kareiva, H. Tallis, T. H. Ricketts, G. C. Daily, and S. Polasky, editors. Natural capital: theory and practice of mapping ecosystem services. Oxford University Press, Oxford, New York, USA. http://dx.doi. org/10.1093/acprof:oso/9780199588992.003.0012

Chan, K. M. A., T. Satterfield, and J. Goldstein. 2012. Rethinking ecosystem services to better address and navigate cultural values. Ecological Economics 74:8-18. $\quad$ http://dx.doi.org/10.1016/j. ecolecon.2011.11.011

Costanza, R. 2008. Ecosystem services: multiple classification systems are needed. Biological Conservation 141:350-352. http:// dx.doi.org/10.1016/j.biocon.2007.12.020

Costanza, R., R. D'Arge, R. de Groot, S. Farber, M. Grasso, B. Hannon, K. Limburg, S. Naeem, R. V. O'Neill, J. Paruelo, R. G. Raskin, P. Sutton, and M. van den Belt. 1997. The value of the world's ecosystem services and natural capital. Nature 387:253260. http://dx.doi.org/10.1038/387253a0

Cowling, R. M., B. Egoh, A. T. Knight, P. J. O'Farrell, B. Reyers, M. Rouget, D. J. Roux, A. Welz, and A. Wilhelm-Rechman. 2008. An operational model for mainstreaming ecosystem services for implementation. Proceedings of the National Academy of Sciences of the United States of America 105:9483-9488. http://dx.doi. org/10.1073/pnas.0706559105

CREDOC. 2009. Etude exploratoire pour une évaluation des services rendus par les écosystèmes en France.

Crossman, N. D., B. Burkhard, S. Nedkov, L. Willemen, K. Petz, I. Palomo, E. G. Drakou, B. Martín-Lopez, T. McPhearson, K. Boyanova, R. Alkemade, B. Egoh, M. B. Dunbar, and J. Maes. 2013. A blueprint for mapping and modelling ecosystem services. Ecosystem Services 4:4-14. http://dx.doi.org/10.1016/j.ecoser.2013.02.001

Daily, G. C., editor. 1997. Nature's services: societal dependence on natural ecosystems. Island Press, New York, New York, USA.

Daniel, T. C., A. Muhar, A. Arnberger, O. Aznar, J. W. Boyd, K. M. Chan, R. Costanza, T. Elmqvist, C. G. Flint, P. H. Gobster,
A. Gret-Regamey, R. Lave, S. Muhar, M. Penker, R. G. Ribe, T. Schauppenlehner, T. Sikor, I. Soloviy, M. Spierenburg, K. Taczanowska, J. Tam, and A. von der Dunk. 2012. Contributions of cultural services to the ecosystem services agenda. Proceedings of the National Academy of Science of the United States of America 109:8812-8819. http://dx.doi.org/10.1073/pnas.1114773109

De Groot, R. S. 1992. Functions of nature: evaluation of nature in environmental planning, management and decision making. Wolters-Noordhoff, Groningen.

De Groot, R. S., M. A., Wilson, and R. M. J. Boumans. 2002. A tipology for the classification, description and valuation of ecosystem functions, goods and services. Ecological Economics 41:393-408. http://dx.doi.org/10.1016/S0921-8009(02)00089-7

Dominati, E., M. Patterson, and A. Mackay. 2010. A framework for classifying and quantifying the natural capital and ecosystem services of soils. Ecological Economics 69:1858-1868. http://dx. doi.org/10.1016/j.ecolecon.2010.05.002

Ehrlich, P. R., and H. A. Mooney. 1983. Extinction, substitution, and ecosystem services. BioScience 33:248-254. http://dx.doi. org/10.2307/1309037

Ernstson, H., and S. Sörlin. 2013. Ecosystem services as technology of globalization: on articulating values in urban nature. Ecological Economics 86:274-284. http://dx.doi. org/10.1016/j.ecolecon.2012.09.012

Fagerholm, N., and N. Käyhkö. 2009. Participatory mapping and geographical patterns of the social landscape values of rural communities in Zanzibar, Tanzania. Finnia 187:43-60.

Haygarth, P. M., and K. Ritz. 2009. The future of soils and land use in the UK: soil systems for the provision of land-based ecosystem services. Land Use Policy 26:S187-S197. http://dx.doi. org/10.1016/j.landusepol.2009.09.016

Huntsinger, L., and J. L. Oviedo. 2014. Ecosystem services are social-ecological services in a traditional pastoral system: the case of California's Mediterranean rangelands. Ecology and Society 19(1):8. http://www.ecologyandsociety.org/vol19/iss1/art8/

Kenter, J. O., L. O'Brien, N. Hockley, N. Ravenscroft, I. Fazey, K. N. Irvine, M. S. Reed, M. Christie, E. Brady, R. Bryce, A. Church, N. Cooper, A. Davies, A. Evely, M. Everard, R. Fish, J. A. Fisher, N. Jobstvogt, C. Molloy, J. Orchard-Webb, S. Ranger, M. Ryan, V. Watson, and S. Williams. 2015. What are shared and social values of ecosystems? Ecological Economics 111:86-99. http://dx.doi.org/10.1016/j.ecolecon.2015.01.006

Kienast, F., J. Bolliger, M. Potschin, R. S. de Groot, P. H. Verburg, I. Heller, D. Wascher, and R. Haines-Young. 2009. Assessing landscape functions with broad-scale environmental data: insights gained from a prototype development for Europe. Environmental Management 44:1099-1120. http://dx.doi.org/10.1007/ $\underline{\text { s00267-009-9384-7 }}$

Kumar, M., and P. Kumar. 2008. Valuation of the ecosystem services: a psycho-cultural perspective. Ecological Economics 64:808-819. http://dx.doi.org/10.1016/j.ecolecon.2007.05.008

Lynam, T., W. De Jong, D. Sheil, T. Kusumanto, and K. Evans. 2007. A review of tools for incorporating community knowledge, preferences, and values into decision making in natural resources 
management. Ecology and Society 12:5. http://www.ecologyandsociety. org/vol12/iss1/art5/

Martín-López, B., I. Iniesta-Arandia, M. García-Llorente, I. Palomo, I. Casado-Arzuaga, D. García Del Amo, E. GómezBaggethun, E. Oteros-Rozas, I. Palacios-Agundez, B. Willaarts, J. A. González, F. Santos-Martín, M. Onaindia, C. LópezSantaigo, and C. Montes. 2012. Uncovering ecosystem services bundles through social preferences. PLoS one 7. http://dx.doi. org/10.1371/journal.pone.0038970

Martínez-Harms, M. J., and P. Balvanera. 2012. Methods for mapping ecosystem service supply: a review. International Journal of Biodiversity Science Ecosystem Services \& Management 8:1725. http://dx.doi.org/10.1080/21513732.2012.663792

Maurel, P. 2012. Signes, Données et Représentations Spatiales: Des éléments de sens dans l'élaboration d'un projet de territoire intercommunal. Application au territoire de Thau.

Maynard, S., D. James, and A. Davidson. 2010. The development of an ecosystem services framework for South East Queensland. Environmental Management 45:881-895. http://dx.doi.org/10.1007/ s00267-010-9428-Z

Nahlik, A. M., M. E. Kentula, M. S. Fennessy, and D. H. Landers. 2012. Where is the consensus? A proposed foundation for moving ecosystem service concepts into practice. Ecological Economics 77:27-35. http://dx.doi.org/10.1016/j.ecolecon.2012.01.001

Norgaard, R. B. 2010. Ecosystem services: from eye-opening metaphor to complexity blinder. Ecological Economics 69:12191227. http://dx.doi.org/10.1016/j.ecolecon.2009.11.009

Potschin, M. B. and R. H. Haines-Young. 2011. Ecosystem services: exploring a geographical perspective. Progress in Physical Geography 35:575-594. http://dx.doi.org/10.1177/0309$\underline{133311423172}$

Raymond, C. M., B. A. Bryan, D. H. MacDonald, A. Cast, S. Strathearn, A. Grandgirard, and T. Kalivas. 2009. Mapping community values for natural capital and ecosystem services. Ecological Economics 68:1301-1315. http://dx.doi.org/10.1016/j. ecolecon.2008.12.006

Schaich, H., C. Bieling, and T. Plieninger. 2010. Linking ecosystem services with cultural landscape research. GAIA 19:269-277.

Schulp, C. J. E., R. Alkemade, K. K. Goldewijk, and K. Petz. 2012. Mapping ecosystem functions and services in Eastern Europe using global-scale data sets. International Journal of Biodiversity Science, Ecosystem Services \& Management 8:156168. http://dx.doi.org/10.1080/21513732.2011.645880

Schwarz, E. 1992. A generic model describing the complexification and autonomization of natural systems and its epistemological consequences.In 6th International Conference on Systems Research Informatics and Cybernetics, Baden-Baden, Germany.

Sherrouse, B. C., J. M. Clement, and D. J. Semmens. 2011. A GIS application for assessing, mapping, and quantifying the social values of ecosystem services. Applied Geography 31:748-760. http://dx.doi.org/10.1016/j.apgeog.2010.08.002
Syndicat Mixte du Bassin de Thau (SMBT). 2013. SCoT du Bassin de Thau. Projet d'Aménagement et de Développement Durables du SCoT et de son chapitre individualisé valant SMVM.

Spash, C. L. 2008. How much is that ecosystem in the window? The one with the bio-diverse trail. Environmental Values 17:259284. http://dx.doi.org/10.3197/096327108X303882

Star, S. L., and J. R. Griesemer. 1989. Institutional ecology, 'translations' and boundary objects: amateurs and professionals on Berkeley's Museum of Vertebrate Zoology. Social Studies of Science 19:387-420. http://dx.doi.org/10.1177/030631289019003001

Tengberg, A., S. Fredholm, I. Eliasson, I. Knez, K. Saltzman, and O. Wetterberg. 2012. Cultural ecosystem services provided by landscapes: assessment of heritage values and identity. Ecosystem Services 2:14-26. http://dx.doi.org/10.1016/j.ecoser.2012.07.006

Vallés-Planells, M., F. Galiana, and V. Van Eetvelde. 2014. A classification of landscape services to support local landscape planning. Ecology and Society 19(1):44. http://dx.doi. org/10.5751/es-06251-190144

Vatn, A. 2005. Institutions and the environment. Edward Elgar, Cheltenham, UK.

Westman, W. E. 1977. How much are nature's services worth? Science 197:960-964.

Zhang, W., T. H. Ricketts, C. Kremen, K. Carney, and S. M. Swinton. 2007. Ecosystem services and dis-services to agriculture. Ecological Economics 64:253-260. http://dx.doi.org/10.1016/j. ecolecon.2007.02.024 


\section{Appendix 1 Interview questionnaire}

\section{Table A1.1}

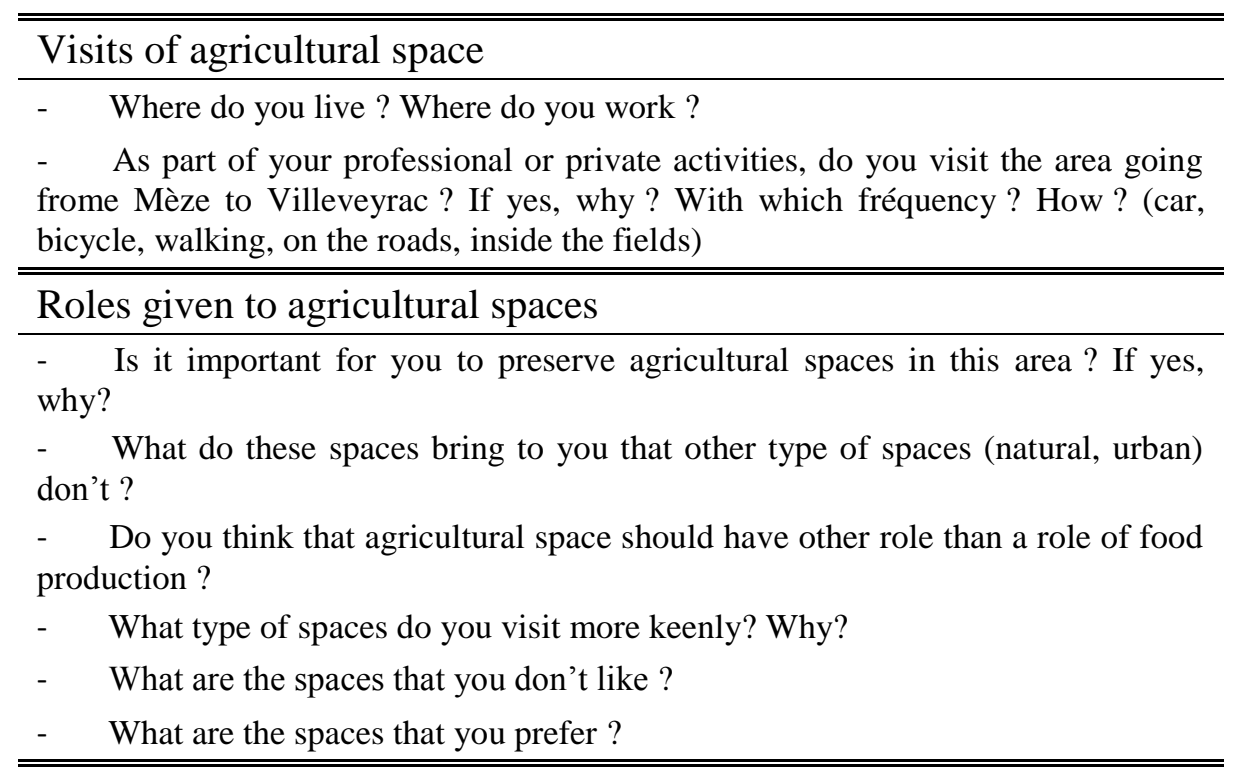

\begin{tabular}{l}
\hline \hline Stakes \\
\hline - In relation to your professional activities, is the presence of agricultural spaces \\
important? \\
- Quels sont pour vous les enjeux en matière agricole autour du bassin de \\
Thau? Et plus particulièrement sur la zone Villeveyrac, Loupian, Mèze? How \\
would you qualify agricultural activity around Villeveyrac, Loupian and Mèze? \\
What is at stake, for you in the agricultural field around the Thau lagoon?
\end{tabular}

On the ecosystem services subject

- $\quad$ Have you already heard before today of the ES concept ?

- If yes, have you already use dit ?

- Is it, according to you, a relevant concept ?

\begin{tabular}{ll}
\hline \hline Questions asked at the beginning of the interview to farmers only \\
\hline - & Since when are you a farmer ? \\
- $\quad$ Where are your lands ? \\
- $\quad$ How did you install yourself here ? \\
- $\quad$ Why did you chose this activity? This type of production? \\
\hline
\end{tabular}




\section{Appendix 2 List of services}

Table A2.1

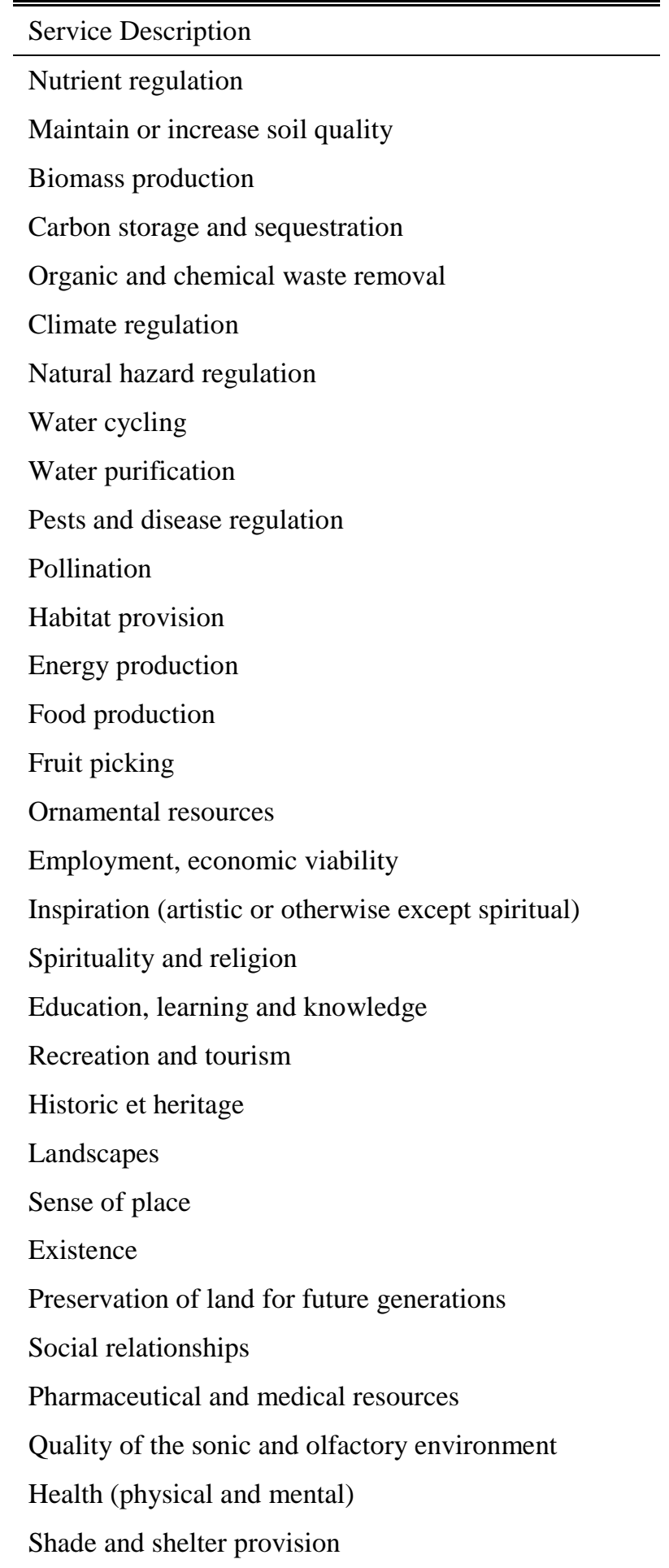




\section{Appendix 3 Published ES typologies used to derive preliminary list of services}

\section{Table A3.1}

\section{Sources}

Chan et al, 2011, Rethinking ecosystem services to better address and navigate cultural values, Ecological economics, 74,08-18

Costanza R. (2008) Ecosystem services: multiple classifications are needed, Biological conservation, 41, 350-352

Credoc, (2009) Etude exploratoire pour une evaluation des services rendus par les ecosystems en France. Application du millenium ecosystem assessment à la France, Collection des rapports $\mathrm{n}^{\circ} 206$

De Groot, et al, 2002, A typology for the classification, description and valuation of ecosystem functions, goods and services, Ecological economics, 41, 393-408

Dominati, E, Patterson, M. Mackay, A. (2010) A framework for classifying and quantifying the natural capital and ecosystem services of soils , Ecological economics, 69, $1858-1868$

\section{Expert meeting on Ecosystem accounting (2011) CICES, Common international classification of ecosystem services}

Haygarth, P.M. et Ritz, K. (2009) The future of soils and land use in the UK: Soil systems for the provision of land-based ecosystem services, Land use policy, 26, 187-197

Kienast et al (2009) Assessing landscape functions with broad-scale environmental data: insight gaines from a prototype development for Europe, Environmental management, 44, $1099-1120$

Kremen, C. et Miles, A. (2012) Ecosystem services in biologically diversified versus conventional farming systems: benefits, externalities, and trade-offs Ecology and Society, $17,40$. 
Maynard, S. et al (2010) The Development of an Ecosystem Services Framework for South East Queensland, Environmental management, DOI 10.1007/s00267-010-9428-z

Millenium ecosystem assessment, 2005

Raymond, C.M. et al (2009) Mapping community values for natural capital and ecosystem services, Ecological economics, 68, 1301-1315

Sherrouse, B, et al (2011) A GIS application for assessing, mapping, and quantifying the social values of ecosystem services, Applied geography, 31, 748-760 